\title{
Conformational Masking and Receptor-Dependent Unmasking of Highly Conserved Env Epitopes Recognized by Non-Neutralizing Antibodies That Mediate Potent ADCC against HIV-1
}

\author{
George K. Lewis ${ }^{1, *}$, Andrés Finzi ${ }^{2}$, Anthony L. DeVico ${ }^{1}$ and Marzena Pazgier ${ }^{1}$ \\ Received: 3 June 2015 ; Accepted: 18 August 2015 ; Published: 18 September 2015 \\ Academic Editor: Andrew Ward \\ 1 Division of Vaccine Research, Institute of Human Virology, University of Maryland School of Medicine, \\ 725 West Lombard Street, Baltimore, MD 21201, USA; adevico@umaryland.edu (A.L.D.V.); \\ mpazgier@umaryland.edu (M.P.) \\ 2 Centre de Recherche du CHUM, Department of Microbiology, Infectiology, and Immunology, \\ Université de Montréal, Montreal, QC H2X 0A9, Canada; andres.finzi@umontreal.ca \\ * Correspondence: glewis@ihv.umaryland.edu; Tel.: +1-443-540-0393; Fax: +1-410-706-4694
}

\begin{abstract}
The mechanism of antibody-mediated protection is a major focus of HIV-1 vaccine development and a significant issue in the control of viremia. Virus neutralization, Fc-mediated effector function, or both, are major mechanisms of antibody-mediated protection against HIV-1, although other mechanisms, such as virus aggregation, are known. The interplay between virus neutralization and Fc-mediated effector function in protection against HIV-1 is complex and only partially understood. Passive immunization studies using potent broadly neutralizing antibodies (bnAbs) show that both neutralization and Fc-mediated effector function provides the widest dynamic range of protection; however, a vaccine to elicit these responses remains elusive. By contrast, active immunization studies in both humans and non-human primates using HIV-1 vaccine candidates suggest that weakly neutralizing or non-neutralizing antibodies can protect by Fc-mediated effector function, albeit with a much lower dynamic range seen for passive immunization with bnAbs. HIV-1 has evolved mechanisms to evade each type of antibody-mediated protection that must be countered by a successful AIDS vaccine. Overcoming the hurdles required to elicit bnAbs has become a major focus of HIV-1 vaccine development. Here, we discuss a less studied problem, the structural basis of protection (and its evasion) by antibodies that protect only by potent Fc-mediated effector function.
\end{abstract}

Keywords: Fc; antibody; HIV-1; protection; effector-function; AIDS; vaccine

\section{Introduction}

Antibody-mediated protection against HIV-1 [1,2], HIV-2/SIV [3] or SHIV [4-15] has been demonstrated repeatedly over the last twenty-five years by passive immunization of non-human primates (NHP) with neutralizing antibodies. The recent discovery that some HIV-1 infected people mount clonal broadly neutralizing (bnAb) antibody responses [16,17] has spurred the search for vaccine to elicit bnAbs to prevent HIV-1 transmission. Although a bnAb-based vaccine has become the Holy Grail of HIV-1 vaccine development, it faces significant obstacles in the unusual genetic and structural requirements for neutralization fitness (reviewed or discussed in [18-21]). Here, we discuss the structural basis of a complementary mechanism of antibody-mediated protection against HIV-1; potent Fc-mediated effector function by non-neutralizing antibodies. In contrast to neutralizing antibodies, passive immunization with non-neutralizing antibodies that can only work 
by Fc-mediated effector function have failed to protect against high-dose SHIV challenges in NHPs, although post-infection control of viremia was observed ( [14,22,23], and in preparation). An early report suggested that non-neutralizing antibodies with potent Fc-mediated effector function could passively protect against SIV [24,25] but this was not seen a following study [26]. Taken at face value, these studies seem to disfavor a role of Fc-mediated effector function alone in antibody-mediated protection against HIV-1. However, a large body of literature, ranging from vaccine studies in NHPs and humans to natural infection cohorts, has consistently correlated Fc-mediated effector function by non-neutralizing antibodies with protection against HIV-1 (reviewed in [27-31]). In the following paragraphs, we discuss the structural basis of an example of potent antibody-dependent cellular cytotoxicity (ADCC) mediated by non-neutralizing antibodies, its potential protective role against HIV-1, and evasion strategies used by the virus to circumvent this mechanism of antibody-mediated protection.

\section{Structural Mechanisms Used by HIV to Evade Antibody-Mediated Protection}

HIV-1 can evade neutralizing antibody responses by at least four mechanisms (discussed in [32]). First, highly conserved structures, such as the co-receptor binding domain (CoRBS) of gp120 [32-35], and most likely the membrane proximal region (MPER) of gp41 [36-38], are conformationally masked on pre-fusion trimers of the HIV-1 envelope glycoprotein (Env), becoming unmasked during viral entry. Second, a dense glycan shield shields most of the Env trimer surface and is only penetrated by uncommon bnAbs that use long HCDR3s, extensive somatic hypermutation, or both [39]. Third, marked tolerance for sequence variation in the gp120 hypervariable regions, contributes significantly to neutralization escape (reviewed in [40]). Fourth, the low density of Env trimers on virions disfavors neutralization by inter-spike cross-linking ( $c f$. [41,42]). In contrast to neutralization, much less is known about the evasion of protection by antibodies that depend partially or exclusively on Fc-mediated effector function. In the following paragraphs, we summarize the structural basis for an additional example of conformational masking for non-neutralizing antibodies specific for highly conserved epitopes of the gp41 interactive face of gp120, which mediate potent antibody-dependent cellular cytotoxicity (ADCC) against target cells sensitized by entering virions $[29,43]$ or by virion budding [44,45].

\section{Conformational Changes in Env during Viral Entry and Budding}

It is well established the HIV envelope glycoprotein (Env) undergoes a discrete series of conformational changes during viral entry, traversing an energy landscape that leads ultimately to viral and cell membrane fusion (reviewed in [46-48]). These conformational changes require the stepwise interaction between Env on the virion surface and CD4 on the target cell surface, forming an Env-CD4 complex that interacts with either CCR5 or CXCR4, enabling viral-cell membrane fusion that is mediated by gp41 rearrangements. Recent structural and biophysical studies are shedding new light on the nature of these conformational changes, their relationships to viral entry, and their role in antibody-mediated protection against HIV-1 [32-35,49]. Intra-spike fluorescence energy transfer (FRET) studies [35,49] confirm the long-suspected view that Env is conformationally dynamic on the viral membrane [50]. The FRET studies also suggest that the conformational states spontaneously sampled by unliganded Env trimers correspond to states that are stabilized by receptor and co-receptor interactions during viral entry [35,49]. Similar conclusions were reached in deuterium-exchange studies (HDX) using soluble Env trimer mimetics [49,51]. Taken together, these studies provide an increasingly clear picture of the conformational dynamics of Env as it traverses the energy landscape leading to viral and cell membrane fusion. By contrast, much less is known about the conformational changes in Env during virus assembly and budding.

HIV-1 buds from cells largely as "immature" particles requiring cleavage of Pr55Gag via the viral protease (reviewed in [52]). Cleavage is essential for capsid maturation, rendering the virion infectious. Pr55 $5^{\text {Gag }}$ is targeted to the inner cell membrane by the matrix protein (MA) that also 
interacts with the long cytoplasmic tail of gp41. This interaction affects the conformation of the ectodomain of Env that results in poor fusogenicity of viral spikes until MA is cleaved from Pr55Gag by the viral protease during virus maturation [36,53-56]. The conformational masking of the gp41 MPER region recognized by bnAbs is an immunologic correlate of this change in Env conformation during virus maturation [36]. The nature of these changes in the Env ectodomain and how they are controlled by interaction of the Env cytoplasmic tail with MA are unknown and constitute a significant area of research that remains largely unplumbed.

\section{Identification of Epitope Cluster A of gp120 as a Target for Potent Fc-Mediated Effector Function}

Fc-mediated effector function, especially ADCC, against HIV infected cells has been studied since early in the epidemic [57-60]. A number of studies, both in HIV-1 infected individuals and SIV/SHIV infected rhesus macaques, strongly support a role for this mechanism in the post-infection control of viremia (reviewed in [28]). There is also suggestive evidence that Fc-mediated effector function is involved the prevention of HIV acquisition, which is an open and controversial question (reviewed in [28]). Regardless of this controversy, it has been known for many years that antibodies to both gp120 [59] and gp41 [61] can mediate ADCC against infected cells. Until recently, however, there have been few quantitative studies to define the relationships between epitope specificity and the potency of Fc-mediated effector functions. Our interest in this problem stems from a confluence of studies over the years on epitope imaging Env-mediated membrane fusion $[38,62,63]$, protection in both human [64,65] and NHP [66-69] vaccine studies, and the role of antibodies in post-infection control of viremia in HIV infected people [70-89]. Protection in our NHP vaccine studies, using a conformationally constrained gp120 [90], correlated directly with antibody specificity for CD4-induced epitopes (CD4i epitopes) [66-68] and with ADCC $[67,68]$ measured in the rapid fluorescent ADCC (RFADCC) assay [91]. Protection correlated inversely with the magnitude of antigen-specific $T$ cell responses [67], showing that protection requires not only the correct antibody response but also a "balanced" $\mathrm{T}$ cell response. A "balanced" $\mathrm{T}$ cell response must provide sufficient help for antibody production by B cells without creating sufficient new CD4+ T cell targets that provide a more fertile environment for viral replication, blunting protection (discussed in [21] and demonstrated experimentally in [92]). Based on these observations, we initiated a series of studies to define the CD4i epitope specificities in our antibody binding and effector assays that correlate with protection in our NHP studies.

This work led to the identification Epitope Cluster A in gp120 as a potent target of antibodies that mediate ADCC against target cells sensitized with entering virions [43]. Epitope Cluster A is located in the gp41-interactive region of gp120 [43,93] and it is comprised of two subregions defined by canonical mAbs. The first is A32, which recognizes an epitope associated primarily with the C1 and C2 regions [93-96]. The A32 subregion was shown to be highly immunogenic in HIV infected individuals [45], and RV144 vaccinees [65,97,98], where it is a target of antibodies that mediate ADCC against infected target cells [44,45]. Further, we recently reported that the A32-subregion is a target of vaccine-elicited antibodies in rhesus macaques where protection against repeat, low-dose rectal challenges with SHIV162P3 correlates with binding antibodies to specificity as well as with ADCC [67]. The second is C11, which recognizes an epitope mapping to the 7-stranded $\beta$-sandwich of gp120 [95,96,99]. We have solved the X-ray crystal structure of the A32 subregion [93] and developed a docking model for the $\mathrm{C} 11$ subregion to provide insight into the potential mechanisms by which antibodies to Epitope Cluster A might protect against HIV-1 and how these responses might be evaded. Although we will discuss the structural basis for Epitope Cluster A in this review, it is not unique as an ADCC target epitope region as ADCC responses are elicited by other epitopes in gp120 [59,81,97,100-103] as well as gp41 [22,61,103,104]. It is our hope that the information gleaned from the detailed characterization of Epitope Cluster A will be of use in future studies of these other ADCC target epitopes. 


\section{Structure of the A32 Subregion of Epitope Cluster A}

We recently reported the first structures of the A32 subregion of epitope Cluster A using two mAbs, N5-i5 [43,93] and 2.2c [93]. These mAbs differ in ADCC potency where N5-i5 is approximately 75 -fold more potent than $2.2 \mathrm{c}$ as defined by EC50, the $\mathrm{mAb}$ concentration in $\mathrm{nM}$ required for half-maximal activity [93]. Both mAbs exhibit the same level of maximal cytotoxicity in our ADCC assay [93]. In addition to defining the A32 epitope subregion at the atomic level, our studies provided the first insight into how the mechanism of $\mathrm{mAb}$ binding to the target epitope affects ADCC potency [93]. As shown in Figure 1 N5-i5 contacts gp120 between mobile layer 1 (panels a, b, d) ( $\beta \overline{2}-, \beta \overline{1}$-strands, $\alpha 0$-helix and $\beta \overline{2}-\alpha 0-, \beta \overline{1}-\beta 0$-connecting coils; residues: $51-54,56,58-61$ and 68-80) and mobile layer 2 ( $\alpha 1$-helix, $\beta 4$-strand and $\beta 4-\beta 5$-connecting coil; residues: $103,106-107$, $110,114,217,219$ and 221) of the $C 1$ and $C 2$ regions. Thus, $82 \%$ of the epitope footprint maps to mobile layer $1[95,96]$ and $18 \%$ maps to mobile layer 2 . The paratope of N5-i5 is relatively flat, with a short HCDR3 (10 residues), and electropositive, forming a precise complementary interaction with the electronegative paratope [93]. In addition, N5-i5 is only modestly mutated in comparison with bnAbs that are most often highly mutated [20]. Interestingly, the epitope recognized by $2.2 \mathrm{c}$ is overlapping but distinct from the epitope recognized by N5-i5 (Figure 1). Ninety-four percent of the epitope footprint for 2.2c maps to mobile layer 1 using most of the same contacts used by N5-i5 (Figure 1, panels c and d). Unlike N5-i5, 2.2c gp120-bound structures of A32 and two additional A32-like mAbs and the epitope footprints are highly overlapping with the N5-i5 epitope involving both layer 1 and layer 2 contacts (in preparation). Thus, the 2.2c epitope appears to be a structural outlier in the A32 epitope subregion. It is also a functional outlier in that 2.2c is the least potent of our A32-like mAbs, which are all similar to N5-i5 in ADCC potency [43,93]. The unusual structural and functional properties of 2.2c suggested that its distinct mode of binding might account for its modest potency compared with N5-i5 and the other A32-like mAbs.
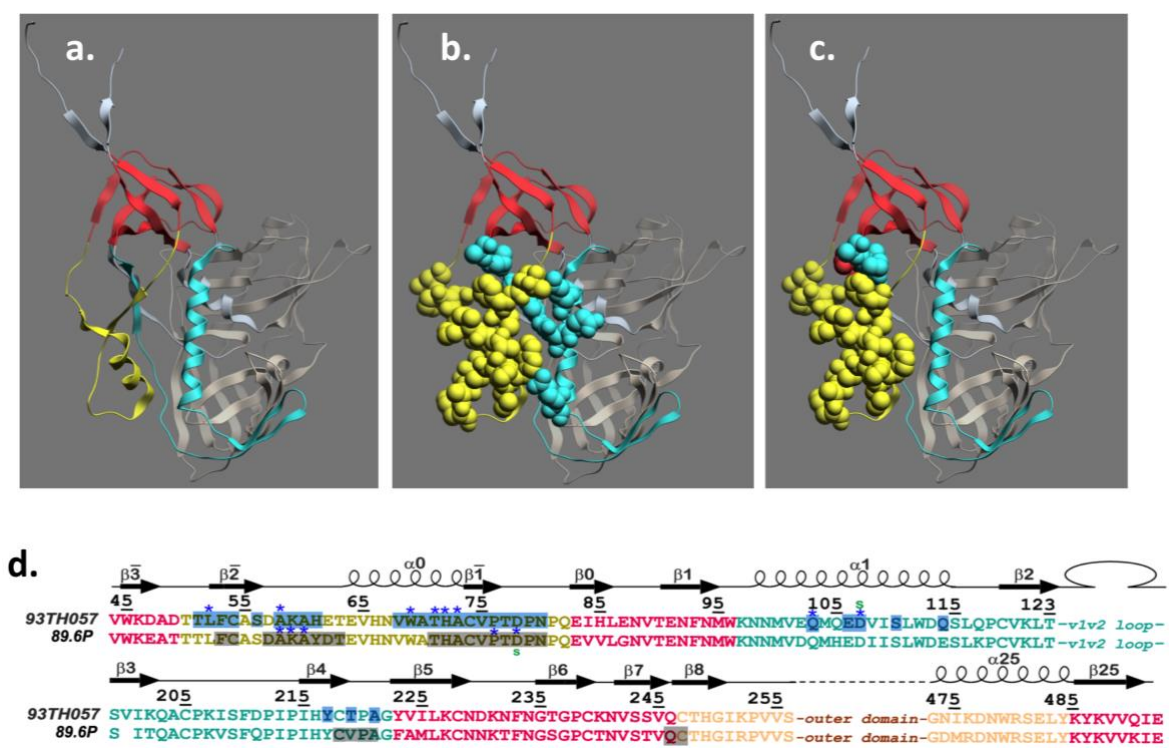

Figure 1. Structure of the A32 sub-region of Epitope Cluster A. Panel (a) depicts the mobile layers of gp120 as defined in [95,96] where layer 1 is yellow, layer 2 is cyan, the 7 -stranded $\beta$-sandwich is red, the gp120 outer domain is bronze and the gp120 inner domain is gray; Panel (b) shows epitope contacts for mAb N5-i5 from [93] rendered as cpk structures and colored according to the mobile layers in panel a; Panel (c) shows epitope contacts for mAb 2.2c from [93] rendered as cpk structures and colored according to the mobile layers in panel a; Panel (d) shows the relationships between epitope contact residues for mAb N5-i5 binding to gp120 ${ }_{93 \text { TH057 }}$ and 2.2c binding to gp120 $0_{89.6 P}$ from [93]. The coloring scheme for mobile layers 1 and 2 as well as the 7 -stranded $\beta$-sandwich are the same as for panel a. 
a.

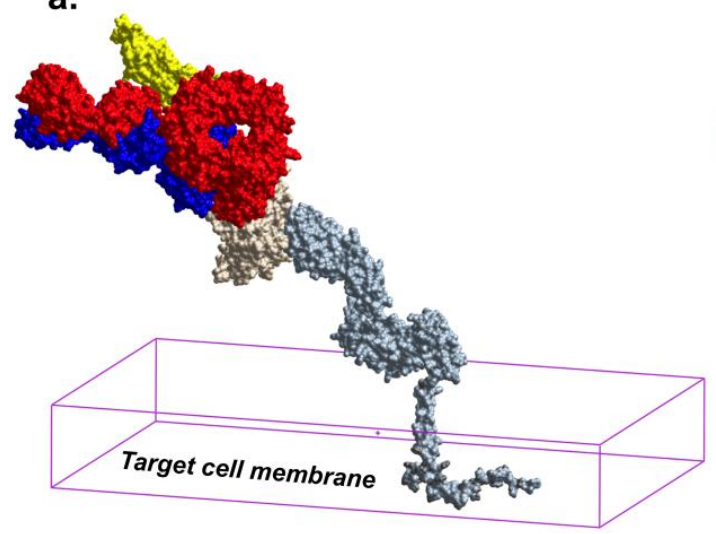

b.

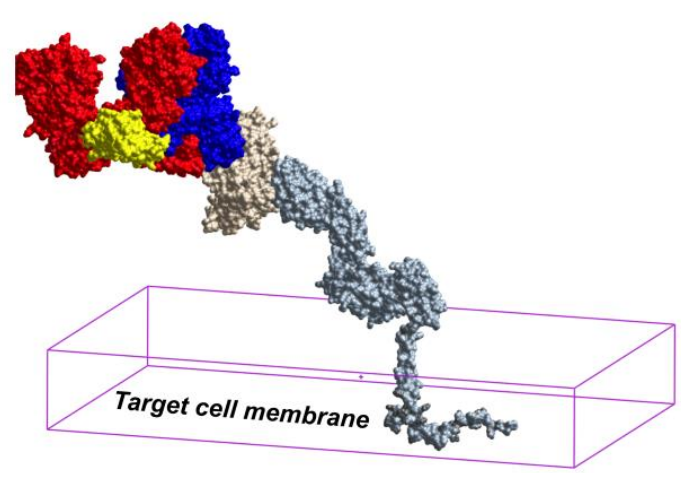

Figure 2. Epitope binding angle determines the orientation of IgG1 toward or away from Fc-receptors on the effector cell membrane. Panel (a) shows the predicted orientation of the CH2 domain of N5-i5 IgG1 when it is bound to a gp120-CD4 complex on the target cell membrane facilitating its recognition by an Fc $\gamma R$ on the effector cell membrane (from [93]). Four domain cell surface CD4 was generated using PDB:1WIO (ectodomain) and PDB:2KLU (transmembrane and cytoplasmic domain). The N5-i5 complex with gp120 used PDB:4H8W and 2.2c complex with gp120 used PDB:4R4F. The 7S IgG1 structure was from PDB:1GY and the human Fc $\gamma$ R3a-human IgG1 Fc complex structure was from PDB:1E4K. Cell surface CD4 is colored as steel, gp120 as beige, IgG1 heavy chain as red, light chain as blue, and Fc $\gamma$ R3a is yellow. The parallelogram represents the target cell membrane. The figure was constructed using ICMPro, Molsoft, LLC, La Jolla, CA, USA; Panel (b) shows the predicted orientation of the $\mathrm{CH} 2$ domain of 2.2c IgG1 when it is bound to a gp120-CD4 complex on the target cell membrane disfavoring its recognition by an $\mathrm{Fc} \gamma \mathrm{R}$ on the effector cell membrane (from [93]).

\section{Structure of the C11 Subregion of Epitope Cluster A}

Much less is known about the structure of the C11 subregion of Epitope Cluster A although it is a very potent ADCC target in multiple assay formats $[43,44]$. Early studies suggested that the C11 epitope maps to the $C 1$ and C5 regions of gp120 [99]. Further studies confirmed this result placing the C11 epitope in the 7-stranded $\beta$-sandwich of gp120 and C-Terminal extension of gp120 (Figure 3) ( $[95,96]$ and submitted). We have solved the structure of unliganded C11 and developed a docking model that places the C11 epitope on the same face of gp120 as the A32 epitope subregion but without overlap (submitted). While this model is being tested in additional crystallization trials, it is consistent with our aggregate data and suggests an additional example of conformational epitope masking by which HIV-1 evades a potentially protective antibody response. As discussed above, the CoRBS and MPER are examples of conformationally masked epitopes recognized by neutralizing antibodies, which can also mediate ADCC in many cases [43,105-107]. 

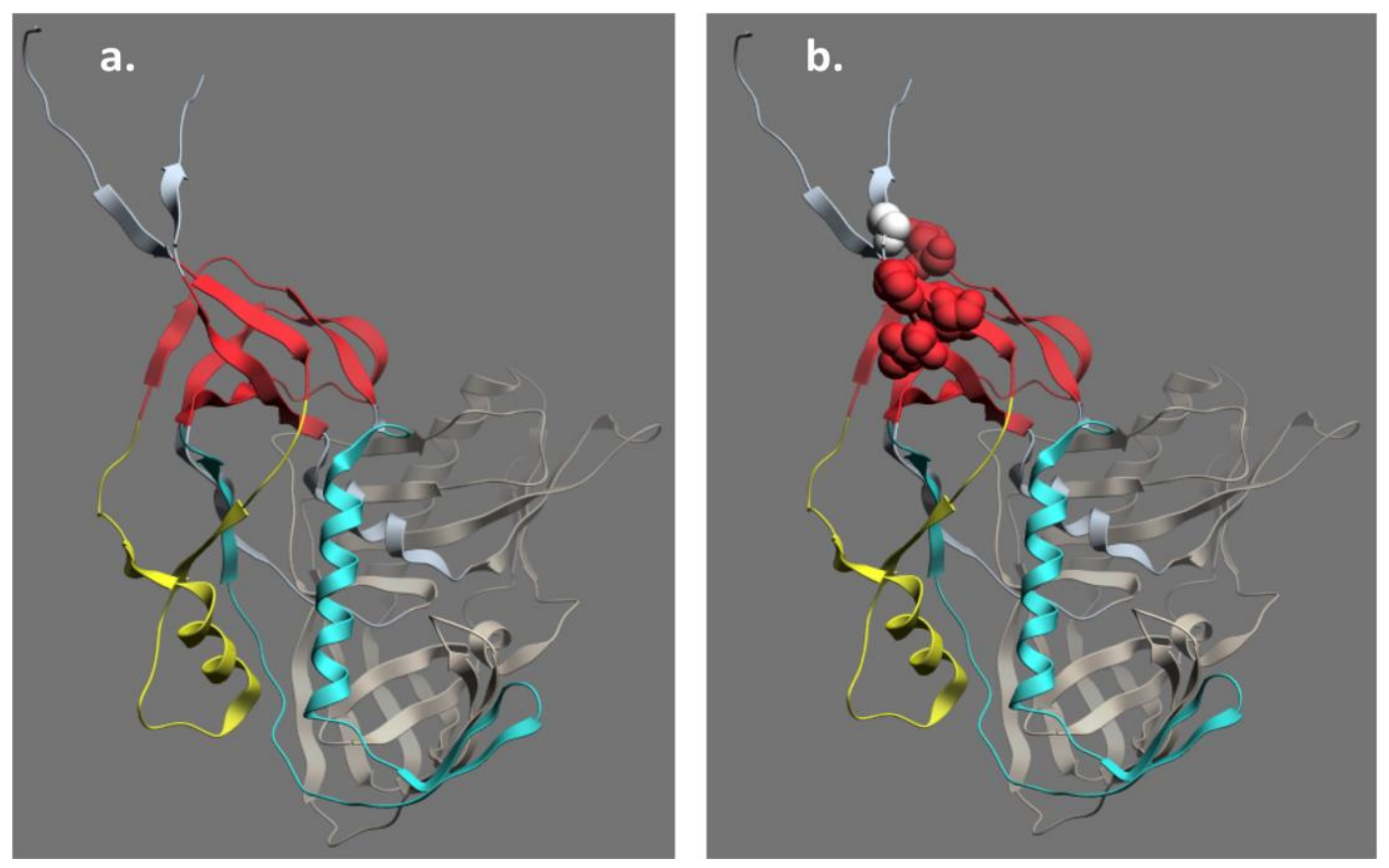

Figure 3. Structure of the C11 sub-region of Epitope Cluster A. Panel (a) shows the mobile layers of gp120 as defined in $[95,96]$ where layer 1 is yellow, layer 2 is cyan, and the 7 -stranded $\beta$-sandwich is red, the gp120 outer domain is bronze and the gp120 inner domain is gray; Panel (b) shows residues $45,88,491,493$, and 495 that are putative contact sites for C11 [96,99]. The putative C11 contact residues map into the 7-stranded $\beta$-sandwich and the C-Terminal extension of the gp120.

\section{Epitope Cluster A Is Conformationally Masked on Virions and Partially Formed in Unliganded Soluble Env Trimer Analogs}

Our recent studies using fluorescence correlation spectroscopy and confocal/superresolution microscopy show that Epitope Cluster A is buried on virion-associated unliganded Env trimers [108] and becomes exposed during viral entry where it remains exposed long enough to sensitize target cells for ADCC $[29,43,63]$. Surprisingly, epitope Cluster A can also be exposed during virus budding provided sufficient cell surface CD4 is present to trigger its exposure, rendering even infected cells susceptible to killing by A32-like and C11-like antibodies [44,45]. In unliganded soluble SOSIP trimer analogs Epitope Cluster A maps precisely to the regions of gp120 that dock into gp41 during biosynthesis to form stable Env trimers on the viral membrane (Figure 3), which is also consistent with mutagenesis [96,109-114] and structural studies of gp120 monomers [95,96] and cryo-electron microscopy of native Env trimers on virions (reviewed in [115]). By analogy with the highly conserved receptor binding domains of gp120, gp41 can be viewed as a transmembrane "receptor" for gp120 where their non-covalent association occurs during biosynthesis. Of necessity, both the "ligand" elements of gp120 and the "receptor" elements of gp41 are highly conserved, which is likely why they are masked in native Env trimers and unmasked only by the conformational changes that occur consequent to receptor binding. Epitope Cluster A exposure is a consequence of these conformational changes.

In this context, it is useful to consider the structural basis of the gp41 "receptor", the gp120 "ligand" interaction, and their relationships to Epitope Cluster A. As shown in Figure 4, gp120 is non-covalently bound to gp41 where the sheets of its $\mathrm{N}$ - and C-Terminal extensions insert through a hydrophobic four-helix collar formed by the $\alpha 6, \alpha 7, \alpha 8$, and $\alpha 9$ helices of gp41 facing toward the viral membrane. gp120 "docks" into the gp41 "receptor" by interactions of the 7-stranded $\beta$-sandwich and N- and C-Terminal extensions of gp120 with the four-helix collar of gp41. The docking of gp120 into gp41 also involves contacts between the loop connecting the $\beta \overline{2}-, \beta \overline{1}$-strands of mobile layer 1 
of gp120 with $\alpha-7$ helix of prefusion gp41 (or HR1 in post-fusion gp41) that protrudes above the four-helix collar. Thus, the A32 epitope subregion binds the $\alpha 7$ helix of gp41 and the C11 epitope subregion binds the four-helix collar of gp41. These interactions place Epitope Cluster A deep within the unliganded SOSIP Env trimer analog. It is possible that the I559P mutation results in an altered gp41 conformation in the unliganded SOSIP trimer [116] and these details might need to be revised as other structures become available. Nevertheless, based on the collective data from mutagenesis, X-ray crystallography, and cryo-electron microscopy discussed above, it is safe that Epitope Cluster A is buried within the trimer axis. The thermodynamics for Epitope Cluster A masking and unmasking are not known but it is likely that the biosynthetic energy required to form a stable docking of gp120 into gp41 in the trimer context comprises a significant fraction of the energy required for viral-cell membrane fusion. There is an additional element of conformational masking of Epitope Cluster A. The $\alpha 0$ helix is disordered in the Env trimer disrupting the local structure of the A32 epitope subregion as shown in [93]. Taken together, these studies show that conformational masking restricts access to this highly conserved target of non-neutralizing antibodies that mediate potent ADCC. The question becomes that of whether receptor-dependent conformational unmasking of these epitopes provides a sufficient window of opportunity anti-Epitope Cluster A antibodies to impinge HIV-1 infection.

\section{Receptor Dependent Conformational Unmasking of Epitope Cluster A}

Elsewhere, we have discussed in detail the relationships between antibody responses to Epitope Cluster A and protection against HIV-1 acquisition and in post-infection control [28,29]. Here, we will focus on the points during acquisition and post-infection control where Epitope Cluster A becomes unmasked and susceptible to immune attack by antibodies via Fc-mediated effector function. There are two windows of opportunity for antibodies to Epitope Cluster A to reduce HIV-1 infection, during viral entry and viral budding. As pointed out above, we showed recently that Epitope Cluster A is essentially absent from the surfaces of virions [108] but is exposed shortly after binding to cell surface CD4 [63,93] and remains exposed for at least two hours [63], during which the target cell is susceptible to killing by effector cells and anti-Epitope Cluster A antibodies [43]. Our recent study suggests that after virion binding, Epitope Cluster A becomes highly exposed distal to the virological synapse rendering the target cells highly sensitive to Fc-mediated effector function [63]. Thus, the window of opportunity for killing nascently infected cells by anti-Epitope Cluster A antibodies is open for at least two $h$ and probably longer. This time may seem too short to be of significance in blocking HIV-1 infection; however, it is important to note that passive immunization studies suggest that the effective window of opportunity for neutralizing antibodies to block acquisition is no longer than $24 \mathrm{~h}[4,117]$. In this context, passive transfer of non-neutralizing antibodies has not blocked high-dose challenges with SHIV [14,22]. However, it has been reported that A32 as well as a non-neutralizing antibody specific for the gp41 disulfide loop can reduce the number of transmitted SHIV variants in a passive immunization study [118]. The conformational unmasking of Epitope Cluster A occurs as a consequence of stored energy being released consequent to viral entry. There is a largely unappreciated role of cell surface CD4 in the unmasking Epitope Cluster A. We have been unable to expose Epitope Cluster A on free virions using soluble CD4 although this interaction clearly exposes the CoRBS [108]. By contrast, Epitope Cluster A becomes exposed within 5 min after binding to cell surface CD4 [63]. Thus, cell surface CD4 makes an energetic contribution to Env trimer rearrangement that is not recapitulated by soluble CD4. Cell surface CD4 exists as monomers and dimers that can interconvert by redox reactions where a reduced monomer appears to be the primary form used for HIV-1 entry and an oxidized dimer is the primary form for Class II MHC mediated antigen presentation [119-123]. Collectively, these studies point toward an underappreciated role for cell surface CD4 in Epitope Cluster A exposure and target cell sensitization in addition to viral entry that deserves additional study. 


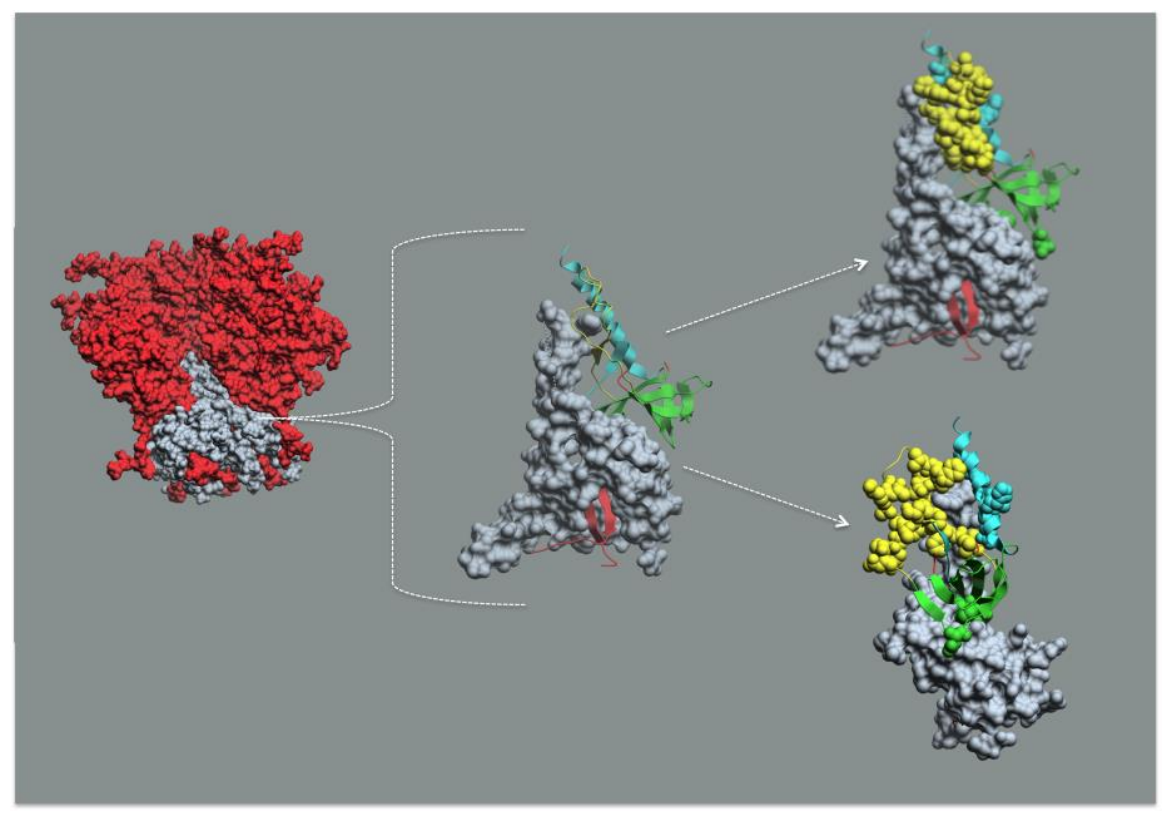

Figure 4. Epitope Cluster A maps into the gp41 docking site for gp120 in Env trimer mimetic structures. The leftmost structure is the soluble SOSIP Env timer mimetic from PDB:4TVP [95] where gp120 is red and gp41 is gray. The middle figure is a gp41 monomer from PDB:4TVP in gray. The gp41 interactive face comprised of elements from mobile layer 1 (yellow), mobile layer 2 (cyan), the 7-stranded $\beta$-sandwich (green), and the $\mathrm{N}$ - and C-Terminal extensions (red) of monomeric gp120 shown as ribbon diagrams. The upper rightmost figure is the same as the middle figure except with the N5-i5 and C11 contact residues rendered as cpk structures. The lower rightmost figure is the same as the upper rightmost figure rotated approximately $90^{\circ}$. Note that the N5-i5 contact residues are in mobile layers 1 and 2 (yellow and cyan), whereas the C11 contact residues are in the 7-stranded $\beta$-sandwich (green). The viral membrane would be at the bottom of each structure.

On the other end of the viral replicative cycle, Epitope Cluster A is also exposed during viral budding from infected cells, rendering them sensitive to killing by ADCC [44,45]. In this instance, Epitope Cluster A is unmasked by the cis interaction of Env trimers with residual CD4 on the infected cell surface [44]. The Env-CD4 interaction is modulated by the HIV-1 accessory proteins Nef and $\mathrm{Vpu}$, which are known to decrease cell-surface levels of CD4 [124,125]. In addition to its role in CD4 degradation, Vpu also antagonizes a restriction factor, Tetherin/BST-2, which normally inhibits retroviral release [126,127]. Viruses lacking Vpu remain trapped at the cell surface resulting in an accumulation of exposed Env [44,128-130]. Therefore, Nef and Vpu can indirectly modulate Env-CD4 interaction at the surface of infected cells through CD4 and BST-2 downregulation $[44,128]$. Cells infected with viruses defective for both Nef and Vpu present enhanced levels of CD4 and Env at the cell-surface, resulting in the exposure of Epitope Cluster A rendering the cells sensitive to killing by antibodies to this region $[44,128]$. However, the vast majority of circulating HIV-1 strains worldwide express functional Nef and Vpu proteins, likely limiting the exposure of CD4i Env epitopes at the surface of infected cells and thus preventing ADCC responses. Therefore, targeting Vpu and Nef ability to down-regulate CD4 and BST-2 or strategies aimed at modifying Env conformation to expose CD4i epitopes could potentially render HIV-1-infected cells susceptible to ADCC and thus have therapeutic utility. In this sense, agents promoting the CD4-bound Env conformation should expose CD4i epitopes that are readily recognized by ADCC-mediating Abs present in sera and cervicovaginal lavages (CVLs) from vaccinated and infected individuals [44,128,131-133]. Importantly, modulating Env conformation at the surface of HIV-1-infected cells has become feasible as a result of the availability of small CD4-mimetic compounds. The prototypes of such compounds, NBD-556 
and NBD-557, were discovered in a screen for inhibitors of gp120-CD4 interaction [134]. These small-molecule $\sim 337$-dalton compounds and recent derivatives (DMJ-I-228) bind in the Phe 43 cavity [135-137], a highly conserved $\sim 150-\AA^{3}$ pocket in the gp120 glycoprotein located at the interface of the inner domain, outer domain, the bridging sheet and the CD4 receptor [138]. CD4-mimetics block gp120-CD4 interaction and induce thermodynamic changes in gp120 similar to those observed upon soluble CD4 (sCD4) binding [139]. Accordingly, these small molecules as well as sCD4 can promote the transition of Env to the CD4-bound conformation, thus sensitizing HIV-1 particles to neutralization by otherwise non-neutralizing CD4i Abs [140,141].

Additional strategies using scaffolded miniproteins targeting critical gp120 elements required for CD4 interaction allowed the identification of CD4-mimetics with nanomolar affinity for gp120 [142]. One of these variants, M48U1, displayed remarkably potent neutralization of three HIV-1 isolates [143]; its crystal structure in complex with HIV-1 gp120 was recently solved, showing that M48U1 engages the Phe 43 cavity in a manner similar to that of cell surface CD4 [144]. Thus, CD4-mimetics might induce gp120 to adopt the CD4-bound conformation, expose CD4i epitopes at the surface of infected cells and thus sensitize them to ADCC-mediated killing. In a recent study we were able to sensitize HIV-1-infected cell to ADCC killing mediated by autologous and heterologous sera [145]. However, whether this was mediated by Epitope Cluster A antibodies present in the sera remains to be determined. In this context, it will be important to determine which, if any, of these small molecules expose Epitope Cluster A in addition to epitopes recognized by neutralizing antibodies.

\section{Conclusions}

In addition to protection mediated by broadly neutralizing antibodies, the studies cited above strongly suggest that the exposure of Epitope Cluster A represents an additional window of opportunity for antibodies to interdict HIV-1. This protection requires Fc-mediated effector function because anti-Epitope Cluster A antibodies are uniformly non-neutralizing. It is useful to frame the discussion by the length of time that the window of opportunity is open for protection by different mechanisms of antibody-mediated protection against HIV-1. Most of the potent broadly neutralizing antibodies recognize epitopes constitutively exposed on infectious virions and neutralize by stabilizing the conformation of unliganded Env $[49,108,146-148]$. Since the window of opportunity for these antibodies is determined solely by epitope exposure on infectious virions, it is relatively wide, which is reflected in ability of bnAbs to protect against high-dose SHIV challenges in vivo $[7,9,10]$, although this window appears to be less than $24 \mathrm{~h}([4,117]$ and reviewed in $[28,29])$. By contrast, the window of opportunity for antibodies to Epitope Cluster A is shorter, most likely on the scale of a few hours following cell surface CD4 binding [43,63]. This is consistent with the inability of A32 to protect against a high-dose SHIV challenge, although it does reduce the number of transmitted variants as reported in [118]. The possibility remains that antibodies to Epitope Cluster A might be sufficient to protect against low-dose SHIV challenges. This is suggested in our recent repeat low-dose SHIV challenge study where protection against acquisition correlated with both ADCC titers and binding antibody titers to the A32 epitope subregion [67]. In contrast to bnAbs, the ease with which anti-Epitope Cluster A antibodies are elicited by vaccination [65-67] supports continued exploration of this region of gp120 as a target for protection against HIV-1 acquisition. Finally, the high frequency of responses to Epitope Cluster A in HIV-1 infected people [43,45], coupled with the possibility of using small molecule drugs and CD4-miniprotein mimetics to expose this region on infected cells [145] offers a unique opportunity to increase post-infection control of viremia and possibly even to reduce or clear the latent reservoir.

Acknowledgments: The authors thank their colleagues at the Institute of Human Virology and The University of Montreal for many stimulating discussions and laboratory efforts supporting the concepts discussed in this review.

Author Contributions: Each author contributed to the ideas and writing of this review. 
Conflicts of Interest: Lewis and DeVico own shares of stock in Profectus Biosciences. The University of Maryland, Baltimore, manages this conflict pursuant to state and federal laws.

\section{References}

1. Emini, E.A.; Nara, P.L.; Schleif, W.A.; Lewis, J.A.; Davide, J.P.; Lee, D.R.; Kessler, J.; Conley, S.; Matsushita, S.; Putney, S.D.; et al. Antibody-mediated in vitro neutralization of human immunodeficiency virus type 1 abolishes infectivity for chimpanzees. J. Virol. 1990, 64, 3674-3678. [PubMed]

2. Emini, E.A.; Schleif, W.A.; Nunberg, J.H.; Conley, A.J.; Eda, Y.; Tokiyoshi, S.; Putney, S.D.; Matsushita, S.; Cobb, K.E.; Jett, C.M.; et al. Prevention of HIV-1 infection in chimpanzees by gp120 v3 domain-specific monoclonal antibody. Nature 1992, 355, 728-730. [CrossRef] [PubMed]

3. Putkonen, P.; Thorstensson, R.; Ghavamzadeh, L.; Albert, J.; Hild, K.; Biberfeld, G.; Norrby, E. Prevention of HIV-2 and sivsm infection by passive immunization in cynomolgus monkeys. Nature 1991, 352, 436-438. [CrossRef] [PubMed]

4. Foresman, L.; Jia, F.; Li, Z.; Wang, C.; Stephens, E.B.; Sahni, M.; Narayan, O.; Joag, S.V. Neutralizing antibodies administered before, but not after, virulent shiv prevent infection in macaques. AIDS Res. Hum. Retrovir. 1998, 14, 1035-1043. [CrossRef] [PubMed]

5. Baba, T.W.; Liska, V.; Hofmann-Lehmann, R.; Vlasak, J.; Xu, W.; Ayehunie, S.; Cavacini, L.A.; Posner, M.R.; Katinger, H.; Stiegler, G.; et al. Human neutralizing monoclonal antibodies of the IgG1 subtype protect against mucosal simian-human immunodeficiency virus infection. Nat. Med. 2000, 6, 200-206. [PubMed]

6. Mascola, J.R.; Stiegler, G.; VanCott, T.C.; Katinger, H.; Carpenter, C.B.; Hanson, C.E.; Beary, H.; Hayes, D.; Frankel, S.S.; Birx, D.L.; et al. Protection of macaques against vaginal transmission of a pathogenic HIV-1/siv chimeric virus by passive infusion of neutralizing antibodies. Nat. Med. 2000, 6, 207-210. [CrossRef] [PubMed]

7. Parren, P.W.; Marx, P.A.; Hessell, A.J.; Luckay, A.; Harouse, J.; Cheng-Mayer, C.; Moore, J.P.; Burton, D.R. Antibody protects macaques against vaginal challenge with a pathogenic R5 simian/human immunodeficiency virus at serum levels giving complete neutralization in vitro. J. Virol. 2001, 75, 8340-8347. [CrossRef] [PubMed]

8. Hessell, A.J.; Hangartner, L.; Hunter, M.; Havenith, C.E.; Beurskens, F.J.; Bakker, J.M.; Lanigan, C.M.; Landucci, G.; Forthal, D.N.; Parren, P.W.; et al. Fc receptor but not complement binding is important in antibody protection against HIV. Nature 2007, 449, 101-104. [CrossRef] [PubMed]

9. Moldt, B.; Rakasz, E.G.; Schultz, N.; Chan-Hui, P.Y.; Swiderek, K.; Weisgrau, K.L.; Piaskowski, S.M.; Bergman, Z.; Watkins, D.I.; Poignard, P.; et al. Highly potent HIV-specific antibody neutralization in vitro translates into effective protection against mucosal shiv challenge in vivo. Proc. Natl. Acad. Sci. USA 2012, 109, 18921-18925. [CrossRef] [PubMed]

10. Shingai, M.; Donau, O.K.; Plishka, R.J.; Buckler-White, A.; Mascola, J.R.; Nabel, G.J.; Nason, M.C.; Montefiori, D.; Moldt, B.; Poignard, P.; et al. Passive transfer of modest titers of potent and broadly neutralizing anti-HIV monoclonal antibodies block shiv infection in macaques. J. Exp. Med. 2014, 211, 2061-2074. [CrossRef] [PubMed]

11. Hessell, A.J.; Poignard, P.; Hunter, M.; Hangartner, L.; Tehrani, D.M.; Bleeker, W.K.; Parren, P.W.; Marx, P.A.; Burton, D.R. Effective, low-titer antibody protection against low-dose repeated mucosal shiv challenge in macaques. Nat. Med. 2009, 15, 951-954. [CrossRef] [PubMed]

12. Hessell, A.J.; Rakasz, E.G.; Poignard, P.; Hangartner, L.; Landucci, G.; Forthal, D.N.; Koff, W.C.; Watkins, D.I.; Burton, D.R. Broadly neutralizing human anti-HIV antibody $2 \mathrm{~g} 12$ is effective in protection against mucosal shiv challenge even at low serum neutralizing titers. PLoS Pathog. 2009, 5, e1000433. [CrossRef] [PubMed]

13. Hessell, A.J.; Rakasz, E.G.; Tehrani, D.M.; Huber, M.; Weisgrau, K.L.; Landucci, G.; Forthal, D.N.; Koff, W.C.; Poignard, P.; Watkins, D.I.; et al. Broadly neutralizing monoclonal antibodies $2 \mathrm{f5}$ and $4 \mathrm{e} 10$ directed against the human immunodeficiency virus type 1 gp41 membrane-proximal external region protect against mucosal challenge by simian-human immunodeficiency virus shivba-l. J. Virol. 2010, 84, 1302-1313. [CrossRef] [PubMed] 
14. Burton, D.R.; Hessell, A.J.; Keele, B.F.; Klasse, P.J.; Ketas, T.A.; Moldt, B.; Dunlop, D.C.; Poignard, P.; Doyle, L.A.; Cavacini, L.; et al. Limited or no protection by weakly or nonneutralizing antibodies against vaginal shiv challenge of macaques compared with a strongly neutralizing antibody. Proc. Natl. Acad. Sci. USA 2011, 108, 11181-11186. [CrossRef] [PubMed]

15. Shibata, R.; Igarashi, T.; Haigwood, N.; Buckler-White, A.; Ogert, R.; Ross, W.; Willey, R.; Cho, M.W.; Martin, M.A. Neutralizing antibody directed against the HIV-1 envelope glycoprotein can completely block HIV-1/siv chimeric virus infections of macaque monkeys. Nat. Med. 1999, 5, 204-210. [CrossRef] [PubMed]

16. Walker, L.M.; Phogat, S.K.; Chan-Hui, P.Y.; Wagner, D.; Phung, P.; Goss, J.L.; Wrin, T.; Simek, M.D.; Fling, S.; Mitcham, J.L.; et al. Broad and potent neutralizing antibodies from an african donor reveal a new HIV-1 vaccine target. Science 2009, 326, 285-289. [CrossRef] [PubMed]

17. Walker, L.M.; Simek, M.D.; Priddy, F.; Gach, J.S.; Wagner, D.; Zwick, M.B.; Phogat, S.K.; Poignard, P.; Burton, D.R. A limited number of antibody specificities mediate broad and potent serum neutralization in selected HIV-1 infected individuals. PLoS Pathog. 2010, 6, e1001028. [CrossRef] [PubMed]

18. Burton, D.R.; Mascola, J.R. Antibody responses to envelope glycoproteins in HIV-1 infection. Nat. Immunol. 2015, 16, 571-576. [CrossRef] [PubMed]

19. Lewis, G.K. Honing a harder-hitting hammerhead improves broadly neutralizing antibody breadth and potency. J. Clin. Investig. 2015, 125, 1-4. [CrossRef] [PubMed]

20. Klein, F.; Diskin, R.; Scheid, J.F.; Gaebler, C.; Mouquet, H.; Georgiev, I.S.; Pancera, M.; Zhou, T.; Incesu, R.B.; $\mathrm{Fu}$, B.Z.; et al. Somatic mutations of the immunoglobulin framework are generally required for broad and potent HIV-1 neutralization. Cell 2013, 153, 126-138. [CrossRef] [PubMed]

21. Lewis, G.K.; DeVico, A.L.; Gallo, R.C. Antibody persistence and t-cell balance: Two key factors confronting HIV vaccine development. Proc. Natl. Acad. Sci. USA 2014, 111, 15614-15621. [CrossRef] [PubMed]

22. Moog, C.; Dereuddre-Bosquet, N.; Teillaud, J.L.; Biedma, M.E.; Holl, V.; van Ham, G.; Heyndrickx, L.; van Dorsselaer, A.; Katinger, D.; Vcelar, B.; et al. Protective effect of vaginal application of neutralizing and nonneutralizing inhibitory antibodies against vaginal shiv challenge in macaques. Mucosal Immunol. 2014, 7, 46-56. [CrossRef] [PubMed]

23. Dugast, A.S.; Chan, Y.; Hoffner, M.; Licht, A.; Nkolola, J.; Li, H.; Streeck, H.; Suscovich, T.J.; Ghebremichael, M.; Ackerman, M.E.; et al. Lack of protection following passive transfer of polyclonal highly functional low-dose non-neutralizing antibodies. PLoS ONE 2014, 9, e97229. [CrossRef] [PubMed]

24. Van Rompay, K.K.; Berardi, C.J.; Dillard_Telm, S.; Tarara, R.P.; Canfield, D.R.; Valverde, C.R.; Montefiori, D.C.; Cole, K.S.; Montelaro, R.C.; Miller, C.J. Passive immunization of newborn rhesus macaques prevents oral simian immunodeficiency virus infection. J. Infect. Dis. 1998, 177, 1247-1259. [CrossRef] [PubMed]

25. Forthal, D.N.; Landucci, G.; Cole, K.S.; Marthas, M.; Becerra, J.C.; van Rompay, K. Rhesus macaque polyclonal and monoclonal antibodies inhibit simian immunodeficiency virus in the presence of human or autologous rhesus effector cells. J. Virol. 2006, 80, 9217-9225. [CrossRef] [PubMed]

26. Florese, R.H.; Van Rompay, K.K.; Aldrich, K.; Forthal, D.N.; Landucci, G.; Mahalanabis, M.; Haigwood, N.; Venzon, D.; Kalyanaraman, V.S.; Marthas, M.L.; et al. Evaluation of passively transferred, nonneutralizing antibody-dependent cellular cytotoxicity-mediating IgG in protection of neonatal rhesus macaques against oral sivmac251 challenge. J. Immunol. 2006, 177, 4028-4036. [CrossRef] [PubMed]

27. Lewis, G.K. Qualitative and quantitative variables that affect the potency of Fc-mediated effector function in vitro and in vivo: Considerations for passive immunization using non-neutralizing antibodies. Curr. HIV Res. 2013, 11, 354-364. [CrossRef] [PubMed]

28. Lewis, G.K. Role of Fc-mediated antibody function in protective immunity against HIV-1. Immunology 2014, 142, 46-57. [CrossRef] [PubMed]

29. Lewis, G.K.; Guan, Y.; Kamin-Lewis, R.; Sajadi, M.; Pazgier, M.; Devico, A.L. Epitope target structures of Fc-mediated effector function during HIV-1 acquisition. Curr. Opin. HIV AIDS 2014, 9, 263-270. [CrossRef] [PubMed]

30. Forthal, D.; Hope, T.J.; Alter, G. New paradigms for functional HIV-specific nonneutralizing antibodies. Curr. Opin. HIV AIDS 2013, 8, 392-400. [CrossRef] [PubMed]

31. Ackerman, M.E.; Dugast, A.S.; Alter, G. Emerging concepts on the role of innate immunity in the prevention and control of HIV infection. Ann. Rev. Med. 2012, 63, 113-130. [CrossRef] [PubMed] 
32. Pancera, M.; Zhou, T.; Druz, A.; Georgiev, I.S.; Soto, C.; Gorman, J.; Huang, J.; Acharya, P.; Chuang, G.Y.; Ofek, G.; et al. Structure and immune recognition of trimeric pre-fusion HIV-1 env. Nature 2014, 514, 455-461. [CrossRef] [PubMed]

33. Julien, J.P.; Cupo, A.; Sok, D.; Stanfield, R.L.; Lyumkis, D.; Deller, M.C.; Klasse, P.J.; Burton, D.R.; Sanders, R.W.; Moore, J.P.; et al. Crystal structure of a soluble cleaved HIV-1 envelope trimer. Science 2013, 342, 1477-1483. [CrossRef] [PubMed]

34. Lyumkis, D.; Julien, J.P.; de Val, N.; Cupo, A.; Potter, C.S.; Klasse, P.J.; Burton, D.R.; Sanders, R.W.; Moore, J.P.; Carragher, B.; et al. Cryo-em structure of a fully glycosylated soluble cleaved HIV-1 envelope trimer. Science 2013, 342, 1484-1490. [CrossRef] [PubMed]

35. Munro, J.B.; Gorman, J.; Ma, X.; Zhou, Z.; Arthos, J.; Burton, D.R.; Koff, W.C.; Courter, J.R.; Smith, A.B., III; Kwong, P.D.; et al. Conformational dynamics of single HIV-1 envelope trimers on the surface of native virions. Science 2014, 346, 759-763. [CrossRef] [PubMed]

36. Joyner, A.S.; Willis, J.R.; Crowe, J.E., Jr.; Aiken, C. Maturation-induced cloaking of neutralization epitopes on HIV-1 particles. PLoS Pathog. 2011, 7, e1002234. [CrossRef] [PubMed]

37. Dimitrov, A.S.; Jacobs, A.; Finnegan, C.M.; Stiegler, G.; Katinger, H.; Blumenthal, R. Exposure of the membrane-proximal external region of HIV-1 gp41 in the course of HIV-1 envelope glycoprotein-mediated fusion. Biochemistry 2007, 46, 1398-1401. [CrossRef] [PubMed]

38. Finnegan, C.M.; Berg, W.; Lewis, G.K.; DeVico, A.L. Antigenic properties of the human immunodeficiency virus transmembrane glycoprotein during cell-cell fusion. J. Virol. 2002, 76, 12123-12134. [CrossRef] [PubMed]

39. Kong, L.; Lee, J.H.; Doores, K.J.; Murin, C.D.; Julien, J.P.; McBride, R.; Liu, Y.; Marozsan, A.; Cupo, A.; Klasse, P.J.; et al. Supersite of immune vulnerability on the glycosylated face of HIV-1 envelope glycoprotein gp120. Nat. Struct. Mol. Biol. 2013, 20, 796-803. [CrossRef] [PubMed]

40. Corti, D.; Lanzavecchia, A. Broadly neutralizing antiviral antibodies. Ann. Rev. Immunol. 2013, 31, 705-742. [CrossRef] [PubMed]

41. Sievers, S.A.; Scharf, L.; West, A.P., Jr.; Bjorkman, P.J. Antibody engineering for increased potency, breadth and half-life. Curr. Opin. HIV AIDS 2015, 10, 151-159. [CrossRef] [PubMed]

42. Galimidi, R.P.; Klein, J.S.; Politzer, M.S.; Bai, S.; Seaman, M.S.; Nussenzweig, M.C.; West, A.P., Jr.; Bjorkman, P.J. Intra-spike crosslinking overcomes antibody evasion by HIV-1. Cell 2015, 160, 433-446. [CrossRef] [PubMed]

43. Guan, Y.; Pazgier, M.; Sajadi, M.M.; Kamin-Lewis, R.; Al-Darmarki, S.; Flinko, R.; Lovo, E.; Wu, X.; Robinson, J.E.; Seaman, M.S.; et al. Diverse specificity and effector function among human antibodies to HIV-1 envelope glycoprotein epitopes exposed by CD4 binding. Proc. Natl. Acad. Sci. USA 2013, 110, E69-E78. [CrossRef] [PubMed]

44. Veillette, M.; Desormeaux, A.; Medjahed, H.; Gharsallah, N.E.; Coutu, M.; Baalwa, J.; Guan, Y.; Lewis, G.; Ferrari, G.; Hahn, B.H.; et al. Interaction with cellular CD4 exposes HIV-1 envelope epitopes targeted by antibody-dependent cell-mediated cytotoxicity. J. Virol. 2014, 88, 2633-2644. [CrossRef] [PubMed]

45. Ferrari, G.; Pollara, J.; Kozink, D.; Harms, T.; Drinker, M.; Freel, S.; Moody, M.A.; Alam, S.M.; Tomaras, G.D.; Ochsenbauer, C.; et al. An HIV-1 gp120 envelope human monoclonal antibody that recognizes a C1 conformational epitope mediates potent antibody-dependent cellular cytotoxicity (adcc) activity and defines a common adcc epitope in human HIV-1 serum. J. Virol. 2011, 85, 7029-7036. [CrossRef] [PubMed]

46. Wilen, C.B.; Tilton, J.C.; Doms, R.W. Molecular mechanisms of HIV entry. Adv. Exp. Med. Biol. 2012, 726, 223-242. [PubMed]

47. Wilen, C.B.; Tilton, J.C.; Doms, R.W. HIV: Cell binding and entry. Cold Spring Harb. Perspect. Med. $2012,2$. [CrossRef] [PubMed]

48. Blumenthal, R.; Durell, S.; Viard, M. HIV entry and envelope glycoprotein-mediated fusion. J. Biol. Chem. 2012, 287, 40841-40849. [CrossRef] [PubMed]

49. Guttman, M.; Cupo, A.; Julien, J.P.; Sanders, R.W.; Wilson, I.A.; Moore, J.P.; Lee, K.K. Antibody potency relates to the ability to recognize the closed, pre-fusion form of HIV Env. Nat. Commun. 2015, 6, 6144. [CrossRef] [PubMed]

50. DeVico, A.L. CD4-induced epitopes in the HIV envelope glycoprotein, gp120. Curr. HIV Res. 2007, 5, 561-571. [CrossRef] [PubMed] 
51. Guttman, M.; Garcia, N.K.; Cupo, A.; Matsui, T.; Julien, J.P.; Sanders, R.W.; Wilson, I.A.; Moore, J.P.; Lee, K.K. CD4-induced activation in a soluble HIV-1 Env trimer. Structure 2014, 22, 974-984. [CrossRef] [PubMed]

52. Sundquist, W.I.; Krausslich, H.G. HIV-1 assembly, budding, and maturation. Cold Spring Harb. Perspect. Med. 2012, 2. [CrossRef]

53. Jiang, J.; Aiken, C. Maturation-dependent human immunodeficiency virus type 1 particle fusion requires a carboxyl-terminal region of the gp41 cytoplasmic tail. J. Virol. 2007, 81, 9999-10008. [CrossRef] [PubMed]

54. Jiang, J.; Aiken, C. Maturation of the viral core enhances the fusion of HIV-1 particles with primary human $\mathrm{t}$ cells and monocyte-derived macrophages. Virology 2006, 346, 460-468. [CrossRef] [PubMed]

55. Wyma, D.J.; Kotov, A.; Aiken, C. Evidence for a stable interaction of gp41 with pr55(gag) in immature human immunodeficiency virus type 1 particles. J. Virol. 2000, 74, 9381-9387. [CrossRef] [PubMed]

56. Murakami, T.; Ablan, S.; Freed, E.O.; Tanaka, Y. Regulation of human immunodeficiency virus type 1 Env-mediated membrane fusion by viral protease activity. J. Virol. 2004, 78, 1026-1031. [CrossRef] [PubMed]

57. Blumberg, R.S.; Paradis, T.; Hartshorn, K.L.; Vogt, M.; Ho, D.D.; Hirsch, M.S.; Leban, J.; Sato, V.L.; Schooley, R.T. Antibody-dependent cell-mediated cytotoxicity against cells infected with the human immunodeficiency virus. J. Infect. Dis. 1987, 156, 878-884. [CrossRef] [PubMed]

58. Lyerly, H.K.; Matthews, T.J.; Langlois, A.J.; Bolognesi, D.P.; Weinhold, K.J. Human T-cell lymphotropic virus IIIB glycoprotein (gp120) bound to CD4 determinants on normal lymphocytes and expressed by infected cells serves as target for immune attack. Proc. Natl. Acad. Sci. USA 1987, 84, 4601-4605. [CrossRef] [PubMed]

59. Lyerly, H.K.; Reed, D.L.; Matthews, T.J.; Langlois, A.J.; Ahearne, P.A.; Petteway, S.R., Jr.; Weinhold, K.J. Anti-gp 120 antibodies from HIV seropositive individuals mediate broadly reactive anti-HIV ADCC. AIDS Res. Hum. Retrovir. 1987, 3, 409-422. [CrossRef] [PubMed]

60. Rook, A.H.; Lane, H.C.; Folks, T.; McCoy, S.; Alter, H.; Fauci, A.S. Sera from HTLV-III/LAV antibody-positive individuals mediate antibody-dependent cellular cytotoxicity against HTLV-III/LAV-infected T cells. J. Immunol. 1987, 138, 1064-1067. [PubMed]

61. Tyler, D.S.; Stanley, S.D.; Zolla-Pazner, S.; Gorny, M.K.; Shadduck, P.P.; Langlois, A.J.; Matthews, T.J.; Bolognesi, D.P.; Palker, T.J.; Weinhold, K.J. Identification of sites within gp41 that serve as targets for antibody-dependent cellular cytotoxicity by using human monoclonal antibodies. J. Immunol. 1990, 145, 3276-3282. [PubMed]

62. Finnegan, C.M.; Berg, W.; Lewis, G.K.; DeVico, A.L. Antigenic properties of the human immunodeficiency virus envelope during cell-cell fusion. J. Virol. 2001, 75, 11096-11105. [CrossRef] [PubMed]

63. Mengistu, M.; Ray, K.; Lewis, G.K.; DeVico, A.L. Antigenic properties of the human immunodeficiency virus envelope glycoprotein gp120 on virions bound to target cells. PLoS Pathog. 2015, 11, e1004772. [CrossRef] [PubMed]

64. Haynes, B.F.; Gilbert, P.B.; McElrath, M.J.; Zolla-Pazner, S.; Tomaras, G.D.; Alam, S.M.; Evans, D.T.; Montefiori, D.C.; Karnasuta, C.; Sutthent, R.; et al. Immune-correlates analysis of an HIV-1 vaccine efficacy trial. N. Engl. J. Med. 2012, 366, 1275-1286. [CrossRef] [PubMed]

65. Bonsignori, M.; Pollara, J.; Moody, M.A.; Alpert, M.D.; Chen, X.; Hwang, K.K.; Gilbert, P.B.; Huang, Y.; Gurley, T.C.; Kozink, D.M.; et al. Antibody-dependent cellular cytotoxicity-mediating antibodies from an HIV-1 vaccine efficacy trial target multiple epitopes and preferentially use the VH1 gene family. J. Virol. 2012, 86, 11521-11532. [CrossRef] [PubMed]

66. DeVico, A.; Fouts, T.; Lewis, G.K.; Gallo, R.C.; Godfrey, K.; Charurat, M.; Harris, I.; Galmin, L.; Pal, R. Antibodies to CD4-induced sites in HIV gp120 correlate with the control of shiv challenge in macaques vaccinated with subunit immunogens. Proc. Natl. Acad. Sci. USA 2007, 104, 17477-17482. [CrossRef] [PubMed]

67. Fouts, T.R.; Bagley, K.; Prado, I.J.; Bobb, K.L.; Schwartz, J.A.; Xu, R.; Zagursky, R.J.; Egan, M.A.; Eldridge, J.H.; LaBranche, C.C.; et al. Balance of cellular and humoral immunity determines the level of protection by HIV vaccines in rhesus macaque models of HIV infection. Proc. Natl. Acad. Sci. USA 2015, 112, E992-E999. [CrossRef] [PubMed] 
68. Thomas, M.A.; Tuero, I.; Demberg, T.; Vargas-Inchaustegui, D.A.; Musich, T.; Xiao, P.; Venzon, D.; LaBranche, C.; Montefiori, D.C.; DiPasquale, J.; et al. HIV-1 CD4-induced (CD4i) gp120 epitope vaccines promote $\mathrm{b}$ and $\mathrm{t}$-cell responses that contribute to reduced viral loads in rhesus macaques. Virology 2014, 471-473, 81-92. [CrossRef] [PubMed]

69. Barouch, D.H.; Alter, G.; Broge, T.; Linde, C.; Ackerman, M.E.; Brown, E.P.; Borducchi, E.N.; Smith, K.M.; Nkolola, J.P.; Liu, J.; et al. HIV-1 vaccines. Protective efficacy of adenovirus/protein vaccines against siv challenges in rhesus monkeys. Science 2015, 349, 320-324. [CrossRef] [PubMed]

70. Wren, L.H.; Chung, A.W.; Isitman, G.; Kelleher, A.D.; Parsons, M.S.; Amin, J.; Cooper, D.A.; Stratov, I.; Navis, M.; Kent, S.J. Specific antibody-dependent cellular cytotoxicity responses associated with slow progression of HIV infection. Immunology 2013, 138, 116-123. [CrossRef] [PubMed]

71. Lambotte, O.; Pollara, J.; Boufassa, F.; Moog, C.; Venet, A.; Haynes, B.F.; Delfraissy, J.F.; Saez-Cirion, A.; Ferrari, G. High antibody-dependent cellular cytotoxicity responses are correlated with strong cd $8 \mathrm{t}$ cell viral suppressive activity but not with b57 status in HIV-1 elite controllers. PLoS ONE 2013, 8, e74855. [CrossRef] [PubMed]

72. Johansson, S.E.; Rollman, E.; Chung, A.W.; Center, R.J.; Hejdeman, B.; Stratov, I.; Hinkula, J.; Wahren, B.; Karre, K.; Kent, S.J.; et al. Nk cell function and antibodies mediating adcc in HIV-1-infected viremic and controller patients. Viral Immunol. 2011, 24, 359-368. [CrossRef] [PubMed]

73. Chung, A.W.; Navis, M.; Isitman, G.; Wren, L.; Silvers, J.; Amin, J.; Kent, S.J.; Stratov, I. Activation of NK cells by adcc antibodies and HIV disease progression. J. Acquir. Immune Defic. Syndr. 2011, 58, 127-131. [CrossRef] [PubMed]

74. Chung, A.W.; Navis, M.; Isitman, G.; Centre, R.; Finlayson, R.; Bloch, M.; Gelgor, L.; Kelleher, A.; Kent, S.J.; Stratov, I. Activation of nk cells by adcc responses during early HIV infection. Viral Immunol. 2011, 24, 171-175. [CrossRef] [PubMed]

75. Chung, A.W.; Isitman, G.; Navis, M.; Kramski, M.; Center, R.J.; Kent, S.J.; Stratov, I. Immune escape from HIV-specific antibody-dependent cellular cytotoxicity (ADCC) pressure. Proc. Natl. Acad. Sci. USA 2011, 108, 7505-7510. [CrossRef] [PubMed]

76. Alter, G.; Teigen, N.; Davis, B.T.; Addo, M.M.; Suscovich, T.J.; Waring, M.T.; Streeck, H.; Johnston, M.N.; Staller, K.D.; Zaman, M.T.; et al. Sequential deregulation of nk cell subset distribution and function starting in acute HIV-1 infection. Blood 2005, 106, 3366-3369. [CrossRef] [PubMed]

77. Nag, P.; Kim, J.; Sapiega, V.; Landay, A.L.; Bremer, J.W.; Mestecky, J.; Reichelderfer, P.; Kovacs, A.; Cohn, J.; Weiser, B.; et al. Women with cervicovaginal antibody-dependent cell-mediated cytotoxicity have lower genital HIV-1 RNA loads. J. Infect. Dis. 2004, 190, 1970-1978. [CrossRef] [PubMed]

78. Forthal, D.N.; Landucci, G.; Keenan, B. Relationship between antibody-dependent cellular cytotoxicity, plasma HIV type 1 RNA, and CD4+ lymphocyte count. AIDS Res. Hum. Retrovir. 2001, 17, 553-561. [CrossRef] [PubMed]

79. Ahmad, R.; Sindhu, S.T.; Toma, E.; Morisset, R.; Vincelette, J.; Menezes, J.; Ahmad, A. Evidence for a correlation between antibody-dependent cellular cytotoxicity-mediating anti-HIV-1 antibodies and prognostic predictors of HIV infection. J. Clin. Immunol. 2001, 21, 227-233. [CrossRef] [PubMed]

80. Tranchat, C.; Van de Perre, P.; Simonon-Sorel, A.; Karita, E.; Benchaib, M.; Lepage, P.; Desgranges, C.; Boyer, V.; Trepo, C. Maternal humoral factors associated with perinatal human immunodeficiency virus type-1 transmission in a cohort from kigali, rwanda, 1988-1994. J. Infect. 1999, 39, 213-220. [CrossRef]

81. Baum, L.L.; Cassutt, K.J.; Knigge, K.; Khattri, R.; Margolick, J.; Rinaldo, C.; Kleeberger, C.A.; Nishanian, P.; Henrard, D.R.; Phair, J. HIV-1 gp120-specific antibody-dependent cell-mediated cytotoxicity correlates with rate of disease progression. J. Immunol. 1996, 157, 2168-2173. [PubMed]

82. Jenkins, M.; Landers, D.; Williams-Herman, D.; Wara, D.; Viscarello, R.R.; Hammill, H.A.; Kline, M.W.; Shearer, W.T.; Charlebois, E.D.; Kohl, S. Association between anti-human immunodeficiency virus type 1 (HIV-1) antibody-dependent cellular cytotoxicity antibody titers at birth and vertical transmission of HIV-1. J. Infect. Dis. 1994, 170, 308-312. [CrossRef] [PubMed]

83. Ahmad, A.; Morisset, R.; Thomas, R.; Menezes, J. Evidence for a defect of antibody-dependent cellular cytotoxic (adcc) effector function and anti-HIV gp120/41-specific ADCC-mediating antibody titres in HIV-infected individuals. J. Acquir. Immune Defic. Syndr. 1994, 7, 428-437. [PubMed] 
84. Broliden, K.; Sievers, E.; Tovo, P.A.; Moschese, V.; Scarlatti, G.; Broliden, P.A.; Fundaro, C.; Rossi, P. Antibody-dependent cellular cytotoxicity and neutralizing activity in sera of HIV-1-infected mothers and their children. Clin. Exp. Immunol. 1993, 93, 56-64. [CrossRef] [PubMed]

85. Sawyer, L.A.; Katzenstein, D.A.; Hendry, R.M.; Boone, E.J.; Vujcic, L.K.; Williams, C.C.; Zeger, S.L.; Saah, A.J.; Rinaldo, C.R., Jr.; Phair, J.P.; et al. Possible beneficial effects of neutralizing antibodies and antibody-dependent, cell-mediated cytotoxicity in human immunodeficiency virus infection. AIDS Res. Hum. Retrovir. 1990, 6, 341-356. [CrossRef] [PubMed]

86. Ljunggren, K.; Moschese, V.; Broliden, P.A.; Giaquinto, C.; Quinti, I.; Fenyo, E.M.; Wahren, B.; Rossi, P.; Jondal, M. Antibodies mediating cellular cytotoxicity and neutralization correlate with a better clinical stage in children born to human immunodeficiency virus-infected mothers. J. Infect. Dis. 1990, 161, 198-202. [CrossRef] [PubMed]

87. Ojo-Amaize, E.; Nishanian, P.G.; Heitjan, D.F.; Rezai, A.; Esmail, I.; Korns, E.; Detels, R.; Fahey, J.; Giorgi, J.V. Serum and effector-cell antibody-dependent cellular cytotoxicity (ADCC) activity remains high during human immunodeficiency virus (HIV) disease progression. J. Clin. Immunol. 1989, 9, 454-461. [CrossRef] [PubMed]

88. Goudsmit, J.; Ljunggren, K.; Smit, L.; Jondal, M.; Fenyo, E.M. Biological significance of the antibody response to HIV antigens expressed on the cell surface. Arch. Virol. 1988, 103, 189-206. [CrossRef] [PubMed]

89. Ljunggren, K.; Bottiger, B.; Biberfeld, G.; Karlson, A.; Fenyo, E.M.; Jondal, M. Antibody-dependent cellular cytotoxicity-inducing antibodies against human immunodeficiency virus. Presence at different clinical stages. J. Immunol. 1987, 139, 2263-2267. [PubMed]

90. Fouts, T.R.; Tuskan, R.; Godfrey, K.; Reitz, M.; Hone, D.; Lewis, G.K.; DeVico, A.L. Expression and characterization of a single-chain polypeptide analogue of the human immunodeficiency virus type 1 gp120-CD4 receptor complex. J. Virol. 2000, 74, 11427-11436. [CrossRef] [PubMed]

91. Gomez-Roman, V.R.; Florese, R.H.; Patterson, L.J.; Peng, B.; Venzon, D.; Aldrich, K.; Robert-Guroff, M. A simplified method for the rapid fluorometric assessment of antibody-dependent cell-mediated cytotoxicity. J. Immunol. Methods 2006, 308, 53-67. [CrossRef] [PubMed]

92. Carnathan, D.G.; Wetzel, K.S.; Yu, J.; Lee, S.T.; Johnson, B.A.; Paiardini, M.; Yan, J.; Morrow, M.P.; Sardesai, N.Y.; Weiner, D.B.; et al. Activated CD4+CCR5+ T cells in the rectum predict increased siv acquisition in sivgag/tat-vaccinated rhesus macaques. Proc. Natl. Acad. Sci. USA 2015, 112, 518-523. [CrossRef] [PubMed]

93. Acharya, P.; Tolbert, W.D.; Gohain, N.; Wu, X.; Yu, L.; Liu, T.; Huang, W.; Huang, C.C.; Kwon, Y.D.; Louder, R.K.; et al. Structural definition of an antibody-dependent cellular cytotoxicity response implicated in reduced risk for HIV-1 infection. J. Virol. 2014, 88, 12895-12906. [CrossRef] [PubMed]

94. Moore, J.P.; McCutchan, F.E.; Poon, S.W.; Mascola, J.; Liu, J.; Cao, Y.; Ho, D.D. Exploration of antigenic variation in gp120 from clades a through $\mathrm{f}$ of human immunodeficiency virus type 1 by using monoclonal antibodies. J. Virol. 1994, 68, 8350-8364. [PubMed]

95. Pancera, M.; Majeed, S.; Ban, Y.E.; Chen, L.; Huang, C.C.; Kong, L.; Kwon, Y.D.; Stuckey, J.; Zhou, T.; Robinson, J.E.; et al. Structure of HIV-1 gp120 with gp41-interactive region reveals layered envelope architecture and basis of conformational mobility. Proc. Natl. Acad. Sci. USA 2010, 107, 1166-1171. [CrossRef] [PubMed]

96. Finzi, A.; Xiang, S.H.; Pacheco, B.; Wang, L.; Haight, J.; Kassa, A.; Danek, B.; Pancera, M.; Kwong, P.D.; Sodroski, J. Topological layers in the HIV-1 gp120 inner domain regulate gp41 interaction and CD4-triggered conformational transitions. Mol. Cell 2010, 37, 656-667. [CrossRef] [PubMed]

97. Pollara, J.; Bonsignori, M.; Moody, M.A.; Liu, P.; Alam, S.M.; Hwang, K.K.; Gurley, T.C.; Kozink, D.M.; Armand, L.C.; Marshall, D.J.; et al. HIV-1 vaccine-induced c1 and v2 env-specific antibodies synergize for increased antiviral activities. J. Virol. 2014, 88, 7715-7726. [CrossRef] [PubMed]

98. Tomaras, G.D.; Ferrari, G.; Shen, X.; Alam, S.M.; Liao, H.X.; Pollara, J.; Bonsignori, M.; Moody, M.A.; Fong, Y.; Chen, X.; et al. Vaccine-induced plasma iga specific for the $\mathrm{c} 1$ region of the HIV-1 envelope blocks binding and effector function of IgG. Proc. Natl. Acad. Sci. USA 2013, 110, 9019-9024. [CrossRef] [PubMed]

99. Moore, J.P.; Willey, R.L.; Lewis, G.K.; Robinson, J.; Sodroski, J. Immunological evidence for interactions between the first, second, and fifth conserved domains of the gp120 surface glycoprotein of human immunodeficiency virus type 1. J. Virol. 1994, 68, 6836-6847. [PubMed] 
100. Koup, R.A.; Robinson, J.E.; Nguyen, Q.V.; Pikora, C.A.; Blais, B.; Roskey, A.; Panicali, D.; Sullivan, J.L. Antibody-dependent cell-mediated cytotoxicity directed by a human monoclonal antibody reactive with gp120 of HIV-1. AIDS 1991, 5, 1309-1314. [CrossRef] [PubMed]

101. Alsmadi, O.; Herz, R.; Murphy, E.; Pinter, A.; Tilley, S.A. A novel antibody-dependent cellular cytotoxicity epitope in gp120 is identified by two monoclonal antibodies isolated from a long-term survivor of human immunodeficiency virus type 1 infection. J. Virol. 1997, 71, 925-933. [PubMed]

102. Pollara, J.; Bonsignori, M.; Moody, M.A.; Pazgier, M.; Haynes, B.F.; Ferrari, G. Epitope specificity of human immunodeficiency virus-1 antibody dependent cellular cytotoxicity [adcc] responses. Curr. HIV Res. 2013, 11, 378-387. [CrossRef] [PubMed]

103. Santra, S.; Tomaras, G.D.; Warrier, R.; Nicely, N.; Liao, H.X.; Pollara, J.; Liu, P.; Alam, S.M.; Zhang, R.; Cocklin, S.; et al. Human non-neutralizing HIV-1 envelope monoclonal antibodies limit the number of founder viruses during shiv mucosal infection in rhesus macaques. PLoS Pathog. 2015, 11. [CrossRef] [PubMed]

104. Tudor, D.; Bomsel, M. The broadly neutralizing HIV-1 IgG 2 f5 elicits gp41-specific antibody-dependent cell cytotoxicity in a fcgammari-dependent manner. AIDS 2011, 25, 751-759. [CrossRef] [PubMed]

105. Hezareh, M.; Hessell, A.J.; Jensen, R.C.; van de Winkel, J.G.; Parren, P.W. Effector function activities of a panel of mutants of a broadly neutralizing antibody against human immunodeficiency virus type 1. J. Virol. 2001, 75, 12161-12168. [CrossRef] [PubMed]

106. Moldt, B.; Schultz, N.; Dunlop, D.C.; Alpert, M.D.; Harvey, J.D.; Evans, D.T.; Poignard, P.; Hessell, A.J.; Burton, D.R. A panel of IgG 1 B12 variants with selectively diminished or enhanced affinity for fcgamma receptors to define the role of effector functions in protection against HIV. J. Virol. 2011, 85, 10572-10581. [CrossRef] [PubMed]

107. Moldt, B.; Shibata-Koyama, M.; Rakasz, E.G.; Schultz, N.; Kanda, Y.; Dunlop, D.C.; Finstad, S.L.; Jin, C.; Landucci, G.; Alpert, M.D.; et al. A nonfucosylated variant of the anti-HIV-1 monoclonal antibody B12 has enhanced fcgammariiia-mediated antiviral activity in vitro but does not improve protection against mucosal shiv challenge in macaques. J. Virol. 2012, 86, 6189-6196. [CrossRef] [PubMed]

108. Ray, K.; Mengistu, M.; Yu, L.; Lewis, G.K.; Lakowicz, J.R.; DeVico, A.L. Antigenic properties of the HIV envelope on virions in solution. J. Virol. 2014, 88, 1795-1808. [CrossRef] [PubMed]

109. Helseth, E.; Olshevsky, U.; Furman, C.; Sodroski, J. Human immunodeficiency virus type 1 gp120 envelope glycoprotein regions important for association with the gp41 transmembrane glycoprotein. J. Virol. 1991, 65, 2119-2123. [PubMed]

110. Thali, M.; Furman, C.; Helseth, E.; Repke, H.; Sodroski, J. Lack of correlation between soluble CD4-induced shedding of the human immunodeficiency virus type 1 exterior envelope glycoprotein and subsequent membrane fusion events. J. Virol. 1992, 66, 5516-5524. [PubMed]

111. Yang, X.; Mahony, E.; Holm, G.H.; Kassa, A.; Sodroski, J. Role of the gp120 inner domain beta-sandwich in the interaction between the human immunodeficiency virus envelope glycoprotein subunits. Virology 2003, 313, 117-125. [CrossRef]

112. Leavitt, M.; Park, E.J.; Sidorov, I.A.; Dimitrov, D.S.; Quinnan, G.V., Jr. Concordant modulation of neutralization resistance and high infectivity of the primary human immunodeficiency virus type $1 \mathrm{mn}$ strain and definition of a potential gp41 binding site in gp120. J. Virol. 2003, 77, 560-570. [CrossRef] [PubMed]

113. Sen, J.; Jacobs, A.; Caffrey, M. Role of the HIV gp120 conserved domain 5 in processing and viral entry. Biochemistry 2008, 47, 7788-7795. [CrossRef] [PubMed]

114. Wang, J.; Sen, J.; Rong, L.; Caffrey, M. Role of the HIV gp120 conserved domain 1 in processing and viral entry. J. Biol. Chem. 2008, 283, 32644-32649. [CrossRef] [PubMed]

115. Merk, A.; Subramaniam, S. HIV-1 envelope glycoprotein structure. Curr. Opin. Struct. Biol. 2013, 23, 268-276. [CrossRef] [PubMed]

116. Alsahafi, N.; Debbeche, O.; Sodroski, J.; Finzi, A. Effects of the i559p gp41 change on the conformation and function of the human immunodeficiency virus (HIV-1) membrane envelope glycoprotein trimer. PLoS ONE 2015, 10, e0122111. [CrossRef] [PubMed] 
117. Nishimura, Y.; Igarashi, T.; Haigwood, N.L.; Sadjadpour, R.; Donau, O.K.; Buckler, C.; Plishka, R.J.; Buckler-White, A.; Martin, M.A. Transfer of neutralizing IgG to macaques $6 \mathrm{~h}$ but not $24 \mathrm{~h}$ after shiv infection confers sterilizing protection: Implications for HIV-1 vaccine development. Proc. Natl. Acad. Sci. USA 2003, 100, 15131-15136. [CrossRef] [PubMed]

118. Girard, M.P.; Picot, V.; Longuet, C.; Nabel, G.J. Report of the cent gardes HIV vaccine conference: The b-cell response to HIV. Part 2: Non-neutralizing antibodies: Fondation merieux conference center, veyrier du lac, france 5-7 november 2012. Vaccine 2013, 31, 2984-2987. [CrossRef] [PubMed]

119. Matthias, L.J.; Yam, P.T.; Jiang, X.M.; Vandegraaff, N.; Li, P.; Poumbourios, P.; Donoghue, N.; Hogg, P.J. Disulfide exchange in domain 2 of CD4 is required for entry of HIV-1. Nat. Immunol. 2002, 3, 727-732. [CrossRef] [PubMed]

120. Matthias, L.J.; Yam, P.T.; Jiang, X.M.; Hogg, P.J. Disulfide exchange in CD4. BioFactors 2003, 17, $241-248$. [CrossRef] [PubMed]

121. Maekawa, A.; Schmidt, B.; Fazekas de St Groth, B.; Sanejouand, Y.H.; Hogg, P.J. Evidence for a domain-swapped CD4 dimer as the coreceptor for binding to class II mhc. J. Immunol. 2006, 176, 6873-6878. [CrossRef] [PubMed]

122. Matthias, L.J.; Azimi, I.; Tabrett, C.A.; Hogg, P.J. Reduced monomeric CD4 is the preferred receptor for HIV. J. Biol. Chem. 2010, 285, 40793-40799. [CrossRef] [PubMed]

123. Cerutti, N.; Killick, M.; Jugnarain, V.; Papathanasopoulos, M.; Capovilla, A. Disulfide reduction in CD4 domain 1 or 2 is essential for interaction with HIV glycoprotein 120 (gp120), which impairs thioredoxin-driven CD4 dimerization. J. Biol. Chem. 2014, 289, 10455-10465. [CrossRef] [PubMed]

124. Schwartz, O.; Dautry-Varsat, A.; Goud, B.; Marechal, V.; Subtil, A.; Heard, J.M.; Danos, O. Human immunodeficiency virus type 1 nef induces accumulation of CD4 in early endosomes. J. Virol. 1995, 69, 528-533. [PubMed]

125. Willey, R.L.; Maldarelli, F.; Martin, M.A.; Strebel, K. Human immunodeficiency virus type 1 vpu protein induces rapid degradation of CD4. J. Virol. 1992, 66, 7193-7200. [PubMed]

126. Neil, S.J.; Zang, T.; Bieniasz, P.D. Tetherin inhibits retrovirus release and is antagonized by HIV-1 vpu. Nature 2008, 451, 425-430. [CrossRef] [PubMed]

127. Van Damme, N.; Goff, D.; Katsura, C.; Jorgenson, R.L.; Mitchell, R.; Johnson, M.C.; Stephens, E.B.; Guatelli, J. The interferon-induced protein BST-2 restricts HIV-1 release and is downregulated from the cell surface by the viral vpu protein. Cell Host Microbe 2008, 3, 245-252. [CrossRef] [PubMed]

128. Veillette, M.; Coutu, M.; Richard, J.; Batraville, L.A.; Dagher, O.; Bernard, N.; Tremblay, C.; Kaufmann, D.E.; Roger, M.; Finzi, A. The HIV-1 gp120 CD4-bound conformation is preferentially targeted by antibody-dependent cellular cytotoxicity-mediating antibodies in sera from HIV-1-infected individuals. J. Virol. 2015, 89, 545-551. [CrossRef] [PubMed]

129. Alvarez, R.A.; Hamlin, R.E.; Monroe, A.; Moldt, B.; Hotta, M.T.; Rodriguez Caprio, G.; Fierer, D.S.; Simon, V.; Chen, B.K. HIV-1 vpu antagonism of tetherin inhibits antibody-dependent cellular cytotoxic responses by natural killer cells. J. Virol. 2014, 88, 6031-6046. [CrossRef] [PubMed]

130. Arias, J.F.; Heyer, L.N.; von Bredow, B.; Weisgrau, K.L.; Moldt, B.; Burton, D.R.; Rakasz, E.G.; Evans, D.T. Tetherin antagonism by vpu protects HIV-infected cells from antibody-dependent cell-mediated cytotoxicity. Proc. Natl. Acad. Sci. USA 2014, 111, 6425-6430. [CrossRef] [PubMed]

131. Batraville, L.A.; Richard, J.; Veillette, M.; Labbe, A.C.; Alary, M.; Guedou, F.; Kaufmann, D.E.; Poudrier, J.; Finzi, A.; Roger, M. Short communication: Anti-HIV-1 envelope immunoglobulin GS in blood and cervicovaginal samples of beninese commercial sex workers. AIDS Res. Hum. Retrovir. 2014, 30, 1145-1149. [CrossRef] [PubMed]

132. Richard, J.; Veillette, M.; Batraville, L.A.; Coutu, M.; Chapleau, J.P.; Bonsignori, M.; Bernard, N.; Tremblay, C.; Roger, M.; Kaufmann, D.E.; et al. Flow cytometry-based assay to study HIV-1 gp120 specific antibody-dependent cellular cytotoxicity responses. J. Virol. Methods 2014, 208, 107-114. [CrossRef] [PubMed]

133. Veillette, M.; Coutu, M.; Richard, J.; Batraville, L.A.; Desormeaux, A.; Roger, M.; Finzi, A. Conformational evaluation of HIV-1 trimeric envelope glycoproteins using a cell-based elisa assay. J. Vis. Exp. 2014. [CrossRef] [PubMed] 
134. Zhao, Q.; Ma, L.; Jiang, S.; Lu, H.; Liu, S.; He, Y.; Strick, N.; Neamati, N.; Debnath, A.K. Identification of n-phenyl-n'-(2,2,6,6-tetramethyl-piperidin-4-yl)-oxalamides as a new class of HIV-1 entry inhibitors that prevent gp120 binding to CD4. Virology 2005, 339, 213-225. [CrossRef] [PubMed]

135. LaLonde, J.M.; Kwon, Y.D.; Jones, D.M.; Sun, A.W.; Courter, J.R.; Soeta, T.; Kobayashi, T.; Princiotto, A.M.; $\mathrm{Wu}, \mathrm{X}$; Schon, A.; et al. Structure-based design, synthesis, and characterization of dual hotspot small-molecule HIV-1 entry inhibitors. J. Med. Chem. 2012, 55, 4382-4396. [CrossRef] [PubMed]

136. Lalonde, J.M.; Le-Khac, M.; Jones, D.M.; Courter, J.R.; Park, J.; Schon, A.; Princiotto, A.M.; Wu, X.; Mascola, J.R.; Freire, E.; et al. Structure-based design and synthesis of an HIV-1 entry inhibitor exploiting X-ray and thermodynamic characterization. ACS Med. Chem. Lett. 2013, 4, 338-343. [CrossRef] [PubMed]

137. Madani, N.; Schon, A.; Princiotto, A.M.; Lalonde, J.M.; Courter, J.R.; Soeta, T.; Ng, D.; Wang, L.; Brower, E.T.; Xiang, S.H.; et al. Small-molecule CD4 mimics interact with a highly conserved pocket on HIV-1 gp120. Structure 2008, 16, 1689-1701. [CrossRef] [PubMed]

138. Kwong, P.D.; Wyatt, R.; Robinson, J.; Sweet, R.W.; Sodroski, J.; Hendrickson, W.A. Structure of an HIV gp120 envelope glycoprotein in complex with the CD4 receptor and a neutralizing human antibody. Nature 1998, 393, 648-659. [PubMed]

139. Schon, A.; Madani, N.; Klein, J.C.; Hubicki, A.; Ng, D.; Yang, X.; Smith, A.B., III; Sodroski, J.; Freire, E. Thermodynamics of binding of a low-molecular-weight CD4 mimetic to HIV-1 gp120. Biochemistry 2006, 45, 10973-10980. [CrossRef] [PubMed]

140. Madani, N.; Princiotto, A.M.; Schon, A.; LaLonde, J.; Feng, Y.; Freire, E.; Park, J.; Courter, J.R.; Jones, D.M.; Robinson, J.; et al. CD4-mimetic small molecules sensitize human immunodeficiency virus to vaccine-elicited antibodies. J. Virol. 2014, 88, 6542-6555. [CrossRef] [PubMed]

141. Decker, J.M.; Bibollet-Ruche, F.; Wei, X.; Wang, S.; Levy, D.N.; Wang, W.; Delaporte, E.; Peeters, M.; Derdeyn, C.A.; Allen, S.; et al. Antigenic conservation and immunogenicity of the HIV coreceptor binding site. J. Exp. Med. 2005, 201, 1407-1419. [CrossRef] [PubMed]

142. Martin, L.; Stricher, F.; Misse, D.; Sironi, F.; Pugniere, M.; Barthe, P.; Prado-Gotor, R.; Freulon, I.; Magne, X.; Roumestand, C.; et al. Rational design of a CD4 mimic that inhibits HIV-1 entry and exposes cryptic neutralization epitopes. Nat. Biotechnol. 2003, 21, 71-76. [CrossRef] [PubMed]

143. Van Herrewege, Y.; Morellato, L.; Descours, A.; Aerts, L.; Michiels, J.; Heyndrickx, L.; Martin, L.; Vanham, G. CD4 mimetic miniproteins: Potent anti-HIV compounds with promising activity as microbicides. J. Antimicrob. Chemother. 2008, 61, 818-826. [CrossRef] [PubMed]

144. Acharya, P.; Luongo, T.S.; Louder, M.K.; McKee, K.; Yang, Y.; Kwon, Y.D.; Mascola, J.R.; Kessler, P.; Martin, L.; Kwong, P.D. Structural basis for highly effective HIV-1 neutralization by CD4-mimetic miniproteins revealed by 1.5 a cocrystal structure of gp120 and m48u1. Structure 2013, 21, 1018-1029. [CrossRef] [PubMed]

145. Richard, J.; Veillette, M.; Brassard, N.; Iyer, S.S.; Roger, M.; Martin, L.; Pazgier, M.; Schon, A.; Freire, E.; Routy, J.P.; et al. CD4 mimetics sensitize HIV-1-infected cells to adcc. Proc. Natl. Acad. Sci. USA 2015, 112, E2687-E2694. [CrossRef] [PubMed]

146. Parren, P.W.; Mondor, I.; Naniche, D.; Ditzel, H.J.; Klasse, P.J.; Burton, D.R.; Sattentau, Q.J. Neutralization of human immunodeficiency virus type 1 by antibody to gp120 is determined primarily by occupancy of sites on the virion irrespective of epitope specificity. J. Virol. 1998, 72, 3512-3519. [PubMed]

147. Klasse, P.J.; Sattentau, Q.J. Occupancy and mechanism in antibody-mediated neutralization of animal viruses. J. Gen. Virol. 2002, 83, 2091-2108. [CrossRef] [PubMed]

148. Munro, J.B.; Mothes, W. Structure and dynamics of the native HIV-1 Env trimer. J. Virol. 2015, 89, 5752-5755. [CrossRef] [PubMed]

(C) 2015 by the authors; licensee MDPI, Basel, Switzerland. This article is an open access article distributed under the terms and conditions of the Creative Commons by Attribution (CC-BY) license (http://creativecommons.org/licenses/by/4.0/). 